\title{
A Screen-Printed Sensor Coupled with Flow System for Quantitative Determination of a Novel Promising Anticancer Agent Candidate
}

\author{
Katarzyna Tyszczuk-Rotko ${ }^{1, *(D)}$, Jędrzej Kozak ${ }^{1}$ (D), Małgorzata Sztanke ${ }^{2}$, Krzysztof Sztanke ${ }^{3}$ \\ and Ilona Sadok ${ }^{4}$ (D) \\ 1 Faculty of Chemistry, Institute of Chemical Sciences, Maria Curie-Skłodowska University in Lublin, \\ 20-031 Lublin, Poland; jedrekkozak@onet.pl \\ 2 Chair and Department of Medical Chemistry, Medical University of Lublin, 20-093 Lublin, Poland; \\ malgorzata.sztanke@umlub.pl \\ 3 Laboratory of Bioorganic Synthesis and Analysis, Chair and Department of Medical Chemistry, Medical \\ University of Lublin, 20-093 Lublin, Poland; krzysztofsztanke@umlub.pl \\ 4 Laboratory of Separation and Spectroscopic Method Application, Centre for Interdisciplinary Research, \\ Faculty of Science and Health, The John Paul II Catholic University of Lublin, 20-708 Lublin, Poland; \\ ilona.sadok@kul.pl \\ * Correspondence: ktyszczuk@poczta.umcs.lublin.pl
}

Received: 23 August 2020; Accepted: 11 September 2020; Published: 13 September 2020

\begin{abstract}
A carbon nanofibers modified screen-printed carbon sensor (SPCE/CNFs) was applied for the determination of a novel promising anticancer agent candidate (ethyl 8-(4-methoxyphenyl)-4-oxo-4,6,7,8-tetrahydroimidazo[2,1-c][1,2,4]triazine-3-carboxylate, EIMTC) using square-wave voltammetry (SWV). It is the first method for the quantitative determination of EIMTC. The modified screen-printed sensor exhibited excellent electrochemical activity in reducing EIMTC. The peak current of EIMTC was found to be linear in two concentration ranges of $2.0 \times 10^{-9}-$ $2.0 \times 10^{-8} \mathrm{~mol} \mathrm{~L}^{-1}$ and $2.0 \times 10^{-8}-2.0 \times 10^{-7} \mathrm{~mol} \mathrm{~L}^{-1}$, with a detection limit of $5.0 \times 10^{-10} \mathrm{~mol} \mathrm{~L}^{-1}$. The connection of flow-cell for the SPCE/CNFs with SWV detection allowed for the successful determination of EIMTC in human serum samples. Ultra-high-performance liquid chromatography coupled to electrospray ionization triple quadrupole mass spectrometry (UHPLC-ESI-MS/MS) acted as a comparative method in the serum samples analysis.
\end{abstract}

Keywords: anticancer agent candidate; voltammetric analysis; screen-printed sensor; flow system; liquid chromatography

\section{Introduction}

Ethyl 8-(4-methoxyphenyl)-4-oxo-4,6,7,8-tetrahydroimidazo[2,1-c][1,2,4]triazine-3-carboxylate (PubChem CID: 11507951), namely EIMTC (Figure 1), is an interesting electroactive small molecule for our current electrochemical research needs. EIMTC has been shown to possess a fully defined molecular structure, and a low toxicity in vitro and in vivo [1-3]. The same compound has been reported as the most promising innovative nucleobase-like structure (belonging to a class of fused azaisocytosine-containing congeners) with a broad spectrum of anticancer activity (i.e., in multiple myeloma cells and tumor cells of the cervix and breast) as well as good bioavailability and permeability properties [3]. Its methods of synthesis, a complete structural, physico-chemical and pharmacological characterization, have been published earlier together with all the derivatives belonging to the same class of molecules [1-3]. EIMTC has been proposed as a novel anticancer drug candidate with potential applicability in the treatment of multiple myelomas due to its remarkable antiproliferative activity in 
human multiple myeloma cells (i.e., resistant as well as susceptible to thalidomide) combined with a less toxic effect on normal cells. In addition, this potential anticancer drug candidate has been shown to induce growth arrest in cancer cells and evoke higher necrosis rates in tumor than in non-tumoral cells of the same epithelial origin [3].<smiles>CCOC(=O)c1nnc2n(c1=O)CCN2c1ccc(OC)cc1</smiles>

Figure 1. The structure of the investigated EIMTC.

Despite the above-mentioned utilities, no analytical method of EIMTC determination has been developed as of yet. Therefore, the present paper is aimed at developing and optimizing the first electrochemical procedure that allows the quantitative determination of this novel anticancer agent candidate. In the studies, unmodified and modified with carbon nanofibers screen-printed carbon sensors (SPCE and SPCE/CNFs, respectively) were applied for the voltammetric determination of EIMTC.

It is worth mentioning that electrochemical methods, including among others voltammetry, offer a high sensitivity with relatively low-cost instrumentation and analysis [4]. In turn, due to the mass production nature, availability and low cost of screen-printed electrodes, they are now a good approach to the preparation of voltammetric sensors [5-9]. Moreover, the application of nanomaterials together with screen-printing fabrication is a very actual subject of research of particular importance especially for environmental monitoring and medical diagnostics, but also in other fields of analytical applications [10]. One of the attractive carbon nanomaterials for the sensor fabrication are carbon nanofibers (CNFs). The beginning of their electrochemical applications can be dated to early 2000s [11]. Until now, CNFs have found numerous applications, which are connected with their attractive properties, especially their large number of edge-plane sites and their high surface active group-to-volume ratio $[12,13]$. Furthermore, CNFs can be easily functionalized to suit a particular detection mechanism [13].

\section{Materials and Methods}

\subsection{Instrumentations}

All voltammetric measurements were carried out using an electrochemical potentiostat ( $\mu$ Autolab, Eco Chemie, Utrecht, The Netherlands) connected to a personal computer operated by GPES 4.9 software. The $4 \mathrm{~mm}$ diameter sensors (SPCE - ref. 110 and SPCE/CNFs - ref. 110CNF) were provided by DropSens, Llanera, Spain. The sensors were immersed in a classic quartz cell (volume $10 \mathrm{~mL}$ ) or a commercially available methacrylate wall-jet flow-cell (ref. FLWCL, DropSens, Llanera, Spain). The experiments on flow system were carried out using a peristaltic pump type MS-CA (Ismatec, Wertheim, Germany) and sample injection with a $500 \mu \mathrm{L}$ sample loop (Valco Instruments Co. Inc., Houston, USA).

The images of sensors surface were recorded using a high-resolution scanning electron microscope Quanta 3D FEG (FEI, Hillsboro, USA).

The UHPLC-ESI-MS/MS system was used consisting of a model 1290 infinity ultra-high performance liquid chromatograph (Agilent Technologies, USA) connected to a 6460 triple quadrupole mass spectrometer (Agilent Technologies, USA) equipped with an electrospray ion source (Agilent Jet 
Stream) operating in the positive ion mode. The instrument was controlled using Agilent MassHunter Acquisition software v.B.08. The data were analyzed by Agilent MassHunter Quantitative Analysis software v.B.07. The chromatography was performed on a Zorbax Eclipse Plus-C18 Rapid resolution HT column $(2.1 \mathrm{~mm} \times 50 \mathrm{~mm} \times 1.8 \mu \mathrm{m})$ protected by a Zorbax Eclipse Plus-C18 Narrow Bore Guard Column $(2.1 \mathrm{~mm} \times 12.5 \mathrm{~mm} \times 5 \mu \mathrm{m})$, both purchased from Agilent Technologies.

\subsection{Chemicals}

The EIMTC was synthesized from 2-hydrazinylidene-1-(4-methoxyphenyl)imidazolidine and diethyl 2-hydroxyiminomalonate according to the synthetic approach published earlier [1,2]. The chemical structure of the analyzed compound was determined by consistent spectroscopic data (including IR, ${ }^{1} \mathrm{H}$ NMR, EI-MS), whereas its high level of purity was confirmed by a sharp melting point $\left(150-151^{\circ} \mathrm{C}\right)$ and found elemental analyses being within $\pm 0.4 \%$ of the theoretical values for each element analyzed.

The solutions of sulfuric acid, acetic acid, and acetate buffers of different $\mathrm{pH}$ were prepared from Sigma-Aldrich reagents. The Merck (Darmstadt, Germany) standard solutions of $\mathrm{Ca}^{2+}, \mathrm{Mg}^{2+}, \mathrm{Fe}^{3+}, \mathrm{Cl}^{-}$ as well as Sigma-Aldrich (Saint Louis, USA) reagents (adenine, dopamine, epinephrine, glucose, uric acid, ascorbic acid and estradiol) were used in interference studies. For voltammetric measurements, $1.0 \times 10^{-3} \mathrm{~mol} \mathrm{~L}^{-1}$ solution of EIMTC was prepared in $\mathrm{N}, \mathrm{N}$-dimethylformamide (Sigma-Aldrich, Saint Louis, USA). For UHPLC-ESI-MS/MS analysis, methanol (hypergrade, Merck, Darmstadt, Germany) and formic acid (LC-MS, Sigma-Aldrich, Saint Louis, USA) were used.

\subsection{Sample Preparation}

The $100 \mu \mathrm{L}$ of human serum sample 100-times diluted in ultrapure water (Sigma-Aldrich, Saint Louis, USA) spiked with an appropriate concentration of EIMTC was transferred to a centrifugal tube, mixed with $25 \mu \mathrm{L}$ of $7.5 \%(w / v)$ trichloroacetic acid solution (TCA, Sigma-Aldrich, Saint Louis, USA) for protein precipitation, vortexed well, and centrifuged at $14,000 \times \mathrm{g}$ for $15 \mathrm{~min}$ at $4{ }^{\circ} \mathrm{C}$ (5415R Centrifuge, Eppendorf, Germany). The collected supernatant was centrifuged once again $\left(14,000 \times g, 15 \mathrm{~min}, 4^{\circ} \mathrm{C}\right)$, and the clear aliquot was analyzed in triplicate by the SWV and UHPLC-ESI-MS/MS methods.

\subsection{SWV Analysis}

In the case of measurements performed in a classic electrochemical cell, the standard solution of EIMTC was added to the supporting electrolyte of $0.075 \mathrm{~mol} \mathrm{~L}^{-1} \mathrm{H}_{2} \mathrm{SO}_{4}$, mixed for $45 \mathrm{~s}$ (open circuit potential), and SWV curves were registered. In flow system, in the first step of analysis $2 \mathrm{~mol} \mathrm{~L}^{-1}$ $\mathrm{H}_{2} \mathrm{SO}_{4}$ for $55 \mathrm{~s}$ was directed through the cell in order to clean the electrode surface. Then, $500 \mu \mathrm{L}$ of $0.075 \mathrm{~mol} \mathrm{~L}^{-1}$ solution of $\mathrm{H}_{2} \mathrm{SO}_{4}$ containing an appropriate concentration of EIMTC or the sample added to $0.075 \mathrm{~mol} \mathrm{~L}^{-1}$ solution of $\mathrm{H}_{2} \mathrm{SO}_{4}$ was injected. After $55 \mathrm{~s}$ (open circuit potential) from the moment of sample injection, SWV measurements were carried out. The flow rates of each solution were about $3 \mathrm{~mL} \mathrm{~min}^{-1}$. For $\mathrm{SWV}$, the optimum parameters are as follows: initial potential of $-0.2 \mathrm{~V}$, final potential of $-0.9 \mathrm{~V}$, frequency $(f)$ of $50 \mathrm{~Hz}$, square-wave amplitude $\left(\Delta E_{A}\right)$ of $50 \mathrm{mV}$, and step potential $\left(\Delta E_{\text {step }}\right)$ of $7 \mathrm{mV}$. The signal of EIMTC was measured after subtracting the background.

\subsection{UHPLC-ESI-MS/MS Analysis}

The ionization parameters were as follows: nebulizer: 35 psi; gas temperature: $300{ }^{\circ} \mathrm{C}$; gas flow: $10 \mathrm{~L} \mathrm{~min}^{-1}$; sheath gas temperature: $325^{\circ} \mathrm{C}$; sheath gas flow: $10 \mathrm{~L} \mathrm{~min}^{-1}$; and capillary voltage: $4000 \mathrm{~V}$. The mobile phase consisted of two solutions: A $(0.1 \%(v / v)$ formic acid in water) and B (methanol). The gradient program was as follows: $0-5 \mathrm{~min}-5 \%$ to $70 \% \mathrm{~B} ; 5-7 \mathrm{~min}-5 \% \mathrm{~B}$ (column re-equilibration). The column temperature and mobile phase rate were $40^{\circ} \mathrm{C}$ and $0.3 \mathrm{~mL} \mathrm{~min}^{-1}$, respectively. The injection volume was $5 \mu \mathrm{L}$. The analyte's ions were monitored in Multiple Reaction Monitoring (MRM) mode. MRM transitions: $\mathrm{m} / \mathrm{z} 317>289$ (quantifier, fragmentor: $140 \mathrm{~V}$; collision energy: $20 \mathrm{eV}$ ) and $\mathrm{m} / \mathrm{z} 317$ > 245 (qualifier, fragmentor: $140 \mathrm{~V}$; collision energy: $22 \mathrm{eV}$ ). 


\section{Results and Discussion}

\subsection{Voltammetric Behaviour of EIMTC}

The electrochemical behavior of EIMTC at the unmodified SPCE and carbon nanofibers modified SPCE is shown in Figure 2. Before SWV curve registration, the solution was mixed for $45 \mathrm{~s}$ (open circuit potential). It can be seen that the reduction peaks of EIMTC at the SPCE were weak, while the EIMTC responses were considerably improved at the SPCE/CNFs. The reason for better performance of SPCE/CNFs was explained in our earlier works $[14,15]$. In those papers, the active surface areas of the SPCE and SPCE/CNFs were calculated using cyclic voltammetric studies in $0.1 \mathrm{~mol} \mathrm{~L}^{-1}$ solution of $\mathrm{KCl}$ and $5.0 \times 10^{-3} \mathrm{~mol} \mathrm{~L}^{-1} \mathrm{~K}_{3}\left[\mathrm{Fe}(\mathrm{CN})_{6}\right]$ and the Randles-Sevcik equation. It was found that modification of the electrode increases its active surface (Figure 3 ).

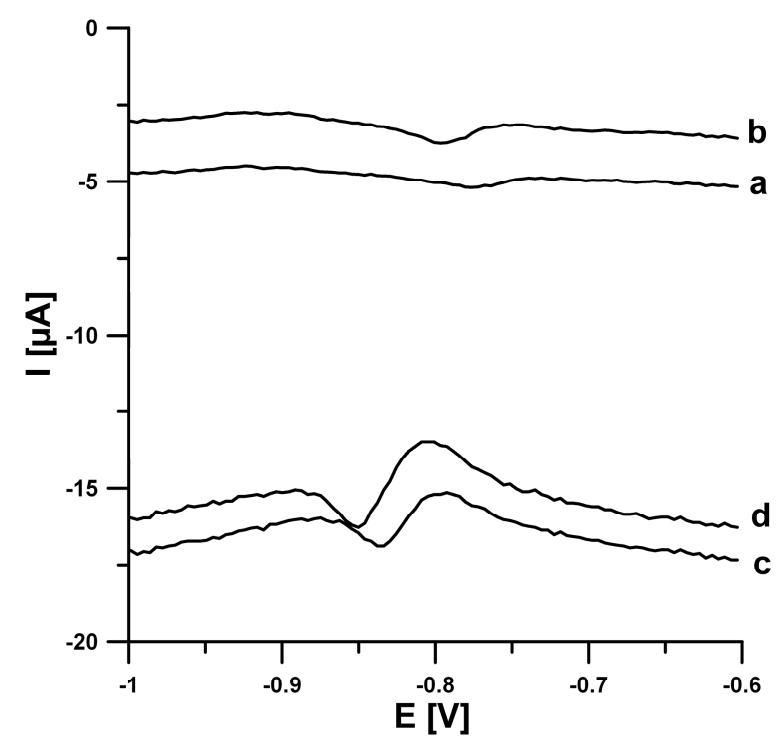

Figure 2. Square-wave voltammograms of $5.0 \times 10^{-7} \mathrm{~mol} \mathrm{~L}^{-1}\left(\mathrm{a}\right.$ and c) and $1.0 \times 10^{-6} \mathrm{~mol} \mathrm{~L}^{-1}(\mathrm{~b}$ and d) EIMTC in $0.1 \mathrm{~mol} \mathrm{~L}^{-1}$ acetate buffer solution of $\mathrm{pH} 4.5$ at the screen-printed carbon sensor (SPCE) (a and b) and carbon nanofibers modified screen-printed carbon sensors (SPCE/CNFs) (c and d). The SWV parameters: open circuit potential, $t$ of $45 \mathrm{~s}$, initial $E$ of $-0.6 \mathrm{~V}$, final $E$ of $-1.0 \mathrm{~V}, f$ of $50 \mathrm{~Hz}, \Delta E_{A}$ of $25 \mathrm{mV}$, and $\Delta E_{\text {step }}$ of $4 \mathrm{mV}$.
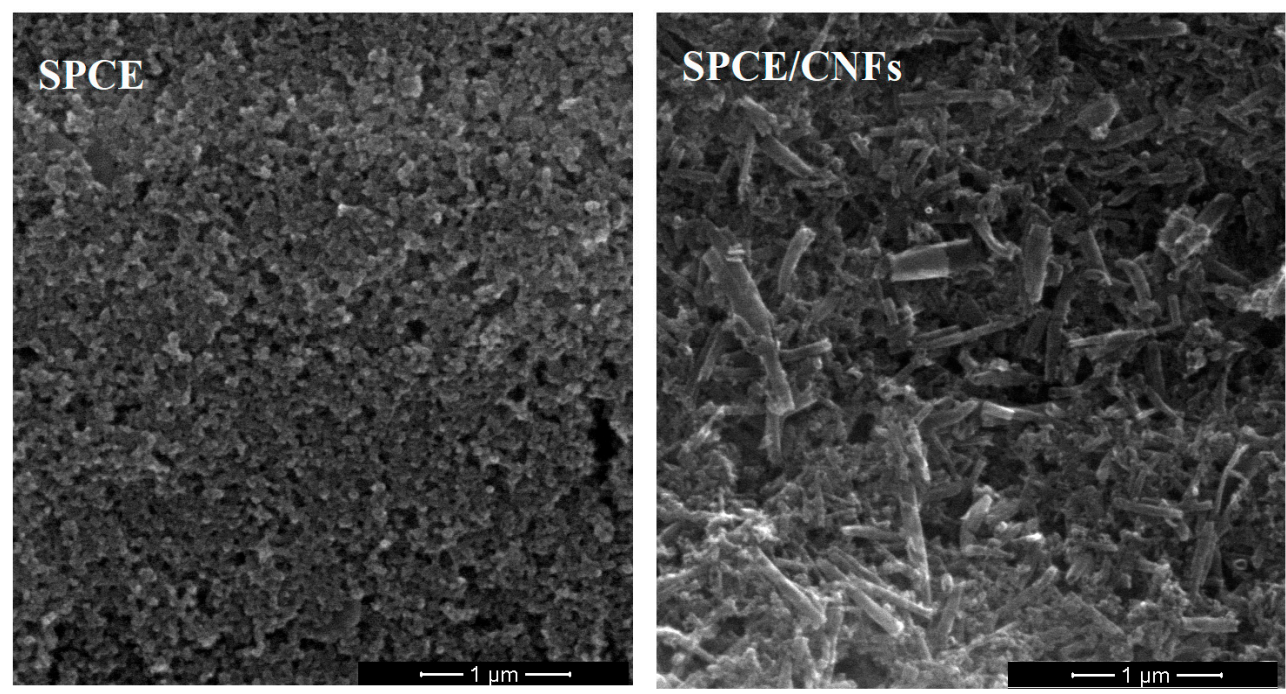

Figure 3. SEM images of SPCE and SPCE/CNFs. 
In the next part of the experiments, cyclic voltammograms (CVs) were recorded in the range of $-0.2-(-0.75) \mathrm{V}$ to get information about the behavior of EIMTC at the SPCE/CNFs. Figure 4A represents $\mathrm{CV}$ curves recorded for $1.0 \times 10^{-5} \mathrm{~mol} \mathrm{~L}^{-1}$ EIMTC in $0.1 \mathrm{~mol} \mathrm{~L}^{-1}$ acetate buffer of $\mathrm{pH} 4.5$ with scan rates $(v)$ of 50,100 , and $150 \mathrm{mV} \mathrm{s}^{-1}$. As it can be seen, well-defined irreversible reduction peaks of EIMTC were obtained. To ascertain the effect of scan rate on the reduction peak current of EIMTC, the scan rate studies were carried out in the range of $20-500 \mathrm{mV} \mathrm{s}^{-1}$. The linearity of peak current $\left(I_{p}\right)$ of EIMTC vs. $v^{1 / 2}$ plot (Figure $4 \mathrm{~B}$ ) indicated that the reduction of EIMTC at the SPCE/CNFs is diffusion controlled, which was further confirmed by the slope value (0.49) of $\log I_{p}$ vs. $\log v$ plot (Figure 4C) [16]. Furthermore, the $I_{p}$ values of $2.0 \times 10^{-7} \mathrm{~mol} \mathrm{~L}^{-1}$ EIMTC were almost stable during changes in the potential $(0-(-0.8) \mathrm{V})$ applied to the electrode, which also confirmed that the reduction of EIMTC is diffusion-controlled at the SPCE/CNFs. While the potential does not significantly affect the EIMTC signal, mixing of the solution prior the SWV curves registration (open circuit potential) is very important. As can be seen in Figure $4 \mathrm{D}$, the $I_{p}$ value of $2.0 \times 10^{-7} \mathrm{~mol} \mathrm{~L}^{-1}$ EIMTC reached maximum at the solution mixing time $(t)$ of $45 \mathrm{~s}$. It is connected with the facilitated diffusion of EIMTC molecules to the electrode surface during solution mixing [17].
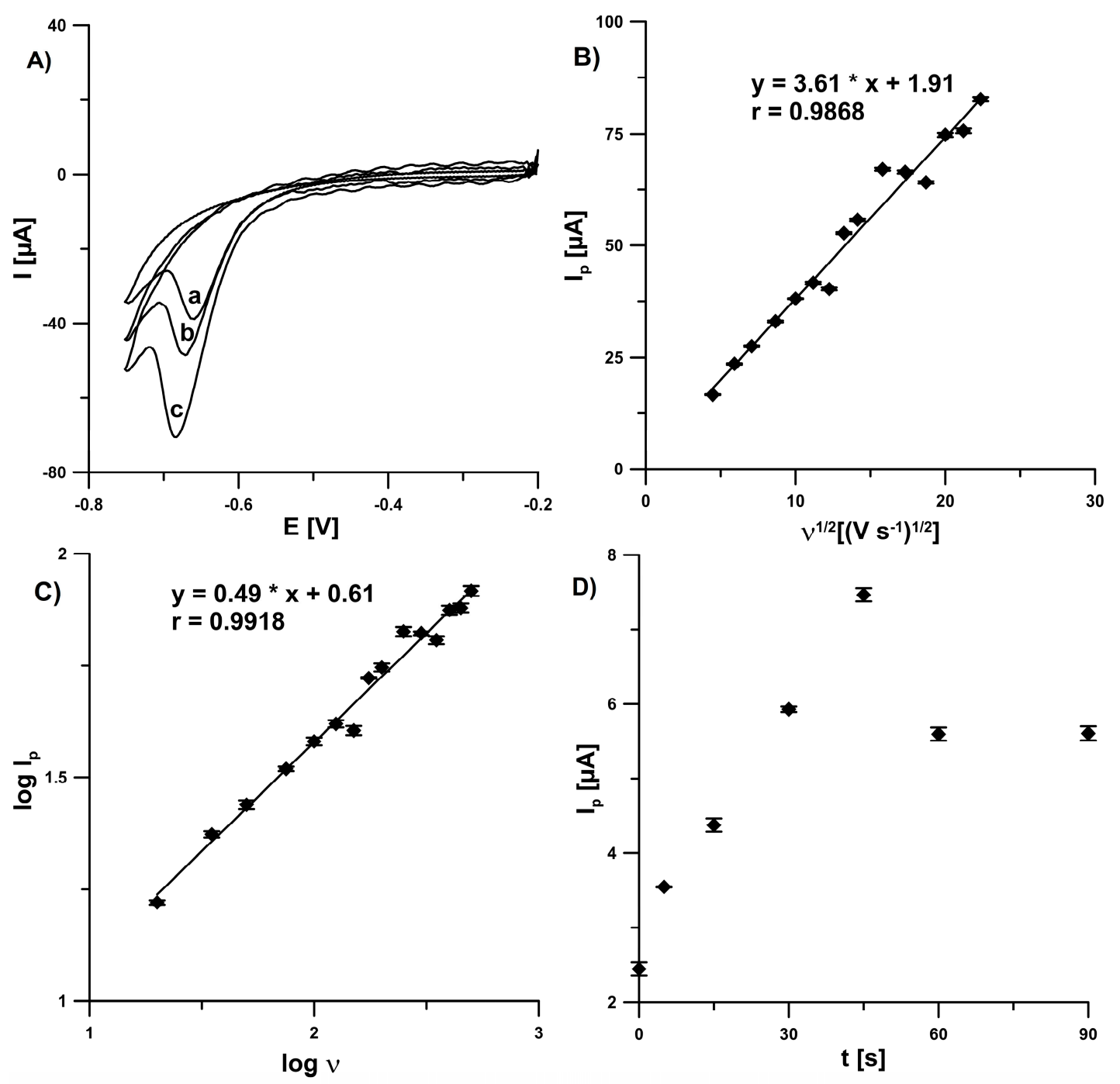

Figure 4. (A) Cyclic voltammograms of $1.0 \times 10^{-5} \mathrm{~mol} \mathrm{~L}^{-1}$ EIMTC at $v$ of 50 (a), 100 (b) and $150 \mathrm{mV} \mathrm{s}^{-1}$ (c). The dependence between (B) Ip and $v^{1 / 2}$ and (C) $\log I p$ and $\log v$. (D) Effect of $t$ on $I_{p}$ of $2.0 \times 10^{-7}$ mol L ${ }^{-1}$ EIMTC (open circuit potential). The average values of $I_{p}$ are shown with the standard deviation of $\mathrm{n}=3$. 


\subsection{Effect of $p H$}

The $\mathrm{pH}$ dependence of $5.0 \times 10^{-7} \mathrm{~mol} \mathrm{~L}^{-1}$ EIMTC at the SPCE/CNFs was investigated using $0.1 \mathrm{~mol} \mathrm{~L}^{-1}$ sulfuric acid, acetic acid, and acetate buffer ( $\mathrm{pH}$ of 3.5-6.0). From the plot of $I_{p}$ of EIMTC vs. $\mathrm{pH}$ (Figure $5 \mathrm{~A}$ ) it is clear that peak current is affected by the $\mathrm{pH}$ value. The best result with respect to sensitivity accompanied with a well-defined response was obtained in the $\mathrm{H}_{2} \mathrm{SO}_{4}$ solution, so this solution was used in further studies. The linearity of peak potential $\left(E_{p}\right)$ of EIMTC vs. pH plot (Figure 5B) was obtained in the $\mathrm{pH}$ range of 2.9-6.0 $(r=0.9950)$. The slope of the equation was found to be $51 \mathrm{mV} \mathrm{pH}^{-1}$. This closeness of the slope to the expected theoretical value of $59 \mathrm{mV} \mathrm{pH}^{-1}$ suggested that the number of electrons is equal to the hydrogen ions taking part in the electrode reaction.
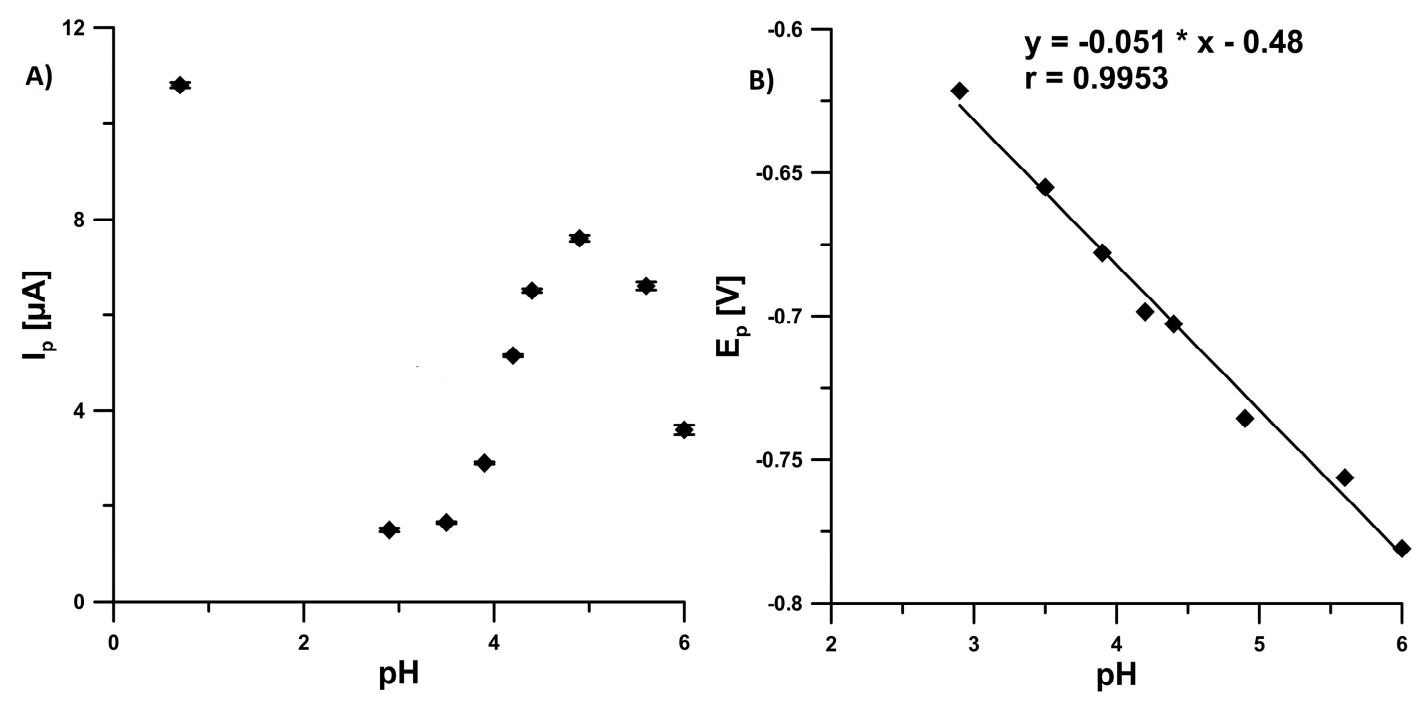

C)
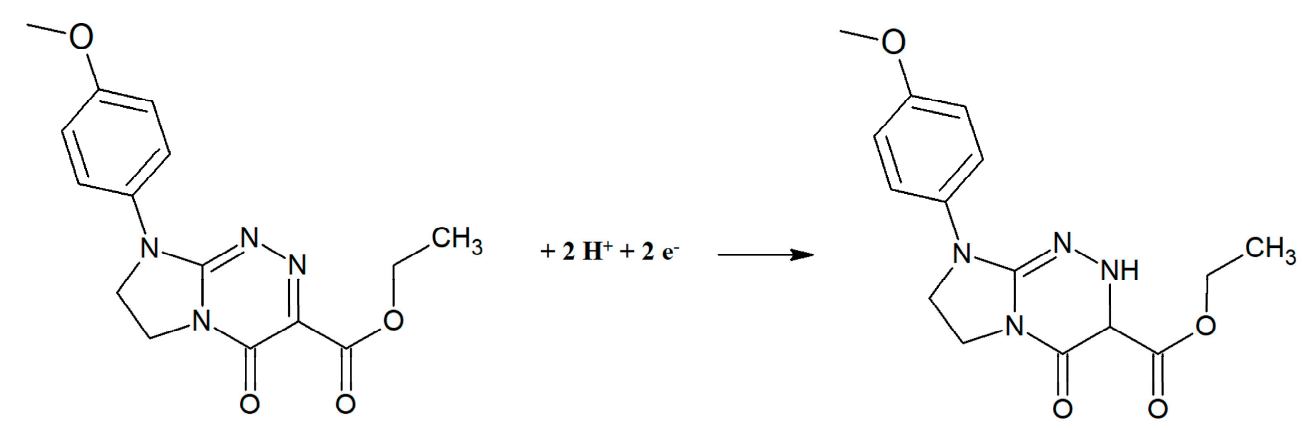

Figure 5. Effect of $\mathrm{pH}$ on: (A) $I_{p}$ and (B) $E_{p}$ of $5.0 \times 10^{-7} \mathrm{~mol} \mathrm{~L}-1$ EIMTC (open circuit potential, $t$ of $45 \mathrm{~s}$ ). The SWV parameters: initial $E$ of $-0.2 \mathrm{~V}$, final $E$ of $-0.9 \mathrm{~V}, f$ of $50 \mathrm{~Hz}, \Delta E_{A}$ of $25 \mathrm{mV}$ and $\Delta E_{\text {step }}$ of $4 \mathrm{mV}$. (C) The mechanism proposed for the reduction of EIMTC. The average values of $I_{p}$ are shown with the standard deviation of $\mathrm{n}=3$.

EIMTC is a small molecule possessing in a privileged triazinone scaffold the azomethine grouping of ketimine type $(\mathrm{C}=\mathrm{N})$ that can be reduced electrochemically. The reduction of this $\mathrm{C}=\mathrm{N}$ grouping in the analyzed molecule, leads to the protonated $\mathrm{CH}-\mathrm{NH}$ grouping. This is consistent with previous studies on electrochemical behavior of monocyclic as well as fused triazinones $[18,19]$. The one-step reduction process at the SPCE/CNFs surface occurs through an electron-gain mechanism, including the transfer of two electrons and two protons (Figure 5C).

Moreover, the effect of selected supporting electrolyte $\left(\mathrm{H}_{2} \mathrm{SO}_{4}\right)$ concentration $\left(0.025-0.2 \mathrm{~mol} \mathrm{~L}^{-1}\right)$ on the peak current of $5.0 \times 10^{-7} \mathrm{~mol} \mathrm{~L}^{-1}$ EIMTC at the SPCE/CNFs was studied. The highest signals were obtained at a concentration of $0.075 \mathrm{~mol} \mathrm{~L}^{-1}$ and at higher concentrations of $\mathrm{H}_{2} \mathrm{SO}_{4}$ the EIMTC signals are almost stable. Therefore, $0.075 \mathrm{~mol} \mathrm{~L}^{-1} \mathrm{H}_{2} \mathrm{SO}_{4}$ solution was selected for further experiments. 


\subsection{Effect of $S W V$ Parameters}

The dependence of the reduction in peak current $\left(I_{p}\right)$ of $5.0 \times 10^{-7} \mathrm{~mol} \mathrm{~L}^{-1}$ EIMTC on the square-wave frequency $(f)$ was studied in the range of $10-125 \mathrm{~Hz}$ at the SPCE/CNFs (Figure $6 \mathrm{~A}$ ). The $I_{p}$ values were found to increase linearly, with increasing $f$ to $50 \mathrm{~Hz}$, and then to decrease. That is why $f$ to $50 \mathrm{~Hz}$ was chosen for further studies. Next, the effect of step potential $\left(\Delta E_{\text {step }}\right)$ on the $5.0 \times 10^{-7}$ mol L ${ }^{-1}$ EIMTC signals was examined from 2 to $9 \mathrm{mV}$ ( $f$ to $50 \mathrm{~Hz}$ and $\Delta E_{A}$ of $25 \mathrm{mV}$ ). The highest EIMTC signal was obtained at $\Delta E_{\text {step }}$ of $7 \mathrm{mV}$ (Figure 6B). Furthermore, the influence of square-wave amplitude $\left(\Delta E_{A}\right)$ on the $5.0 \times 10^{-7} \mathrm{~mol} \mathrm{~L}^{-1}$ EIMTC responses was examined in the rage of $25-100 \mathrm{mV}$ (Figure $6 \mathrm{C}, f$ to $50 \mathrm{~Hz}$ and $\Delta E_{\text {step }}$ of $7 \mathrm{mV}$ ). The maximum value of EIMTC signal $(5.0 \mu \mathrm{A})$ was achieved at $\Delta E_{A}$ of $100 \mathrm{mV}$. However, due to the much lower background current and a slight difference in EIMTC peak current ( $4.6 \mathrm{vs}$. $5.0 \mu \mathrm{A}), \Delta E_{A}$ of $50 \mathrm{mV}$ was selected for further experiments.
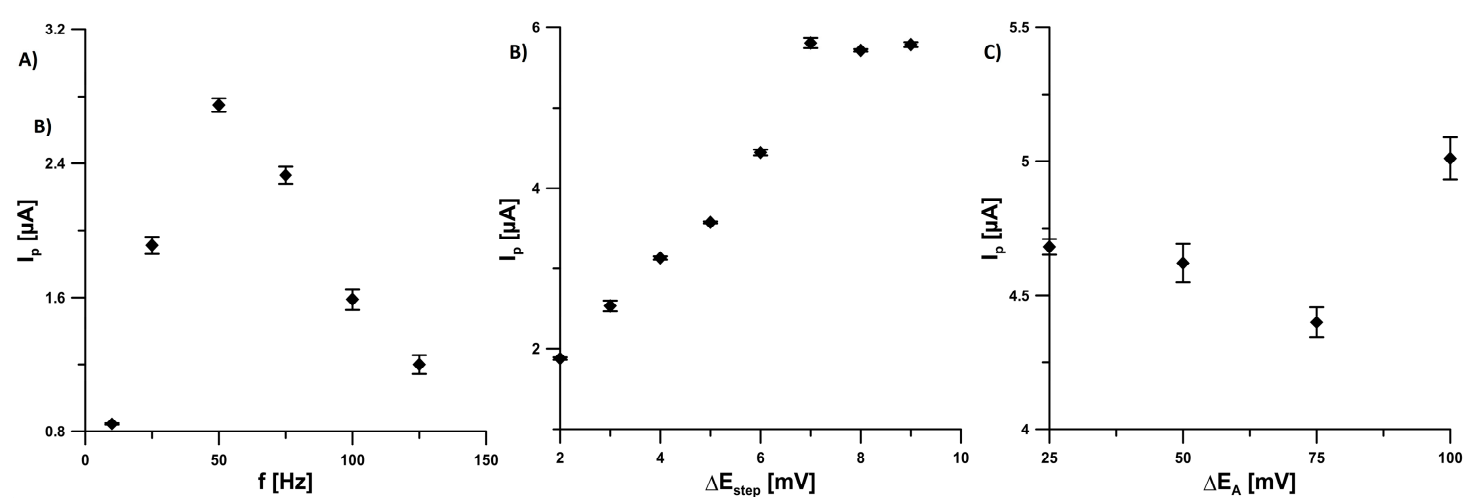

Figure 6. Effect of (A) $f(10-125 \mathrm{~Hz}),($ B $) \Delta E_{\text {step }}(2-9 \mathrm{mV})$ and (C) $\Delta E_{A}(25-100 \mathrm{mV})$ on $5.0 \times 10^{-7} \mathrm{~mol}$ $\mathrm{L}^{-1}$ EIMTC responses. The average values of $I_{p}$ are shown with the standard deviation of $\mathrm{n}=3$.

\subsection{Interferences}

The presence of common ions $\left(\mathrm{Ca}^{2+}, \mathrm{Mg}^{2+}, \mathrm{Fe}^{3+}\right.$, and $\left.\mathrm{Cl}^{-}\right)$and organic compounds (uric acid, ascorbic acid, glucose, adenine, dopamine, epinephrine, and estradiol) in human serum samples may alter electrochemical EIMTC signals and consequently affect the selectivity. The tolerance concentration ratios with respect to $5.0 \times 10^{-7} \mathrm{~mol} \mathrm{~L}^{-1}$ EIMTC for interferences at $10 \%$ level were examined. The results given in Table 1 show that $\mathrm{Fe}^{3+}$, estradiol, and ascorbic acid have a maximum effect on the determination of EIMTC.

Table 1. Results of interference studies for the determination of $5.0 \times 10^{-7} \mathrm{~mol} \mathrm{~L}^{-1}$ EIMTC at the SPCE/CNFs.

\begin{tabular}{cc}
\hline Species & Tolerance Limits \\
\hline $\mathrm{Ca}^{2+}$ & 50 \\
$\mathrm{Mg}^{2+}, \mathrm{Cl}^{-}$, uric acid, glucose, adenine, dopamine & 5 \\
epinephrine & 2.5 \\
$\mathrm{Fe}^{3+}$, estradiol, ascorbic acid & 0.5 \\
\hline
\end{tabular}

The preliminary analysis of human serum samples spiked with $5.0 \times 10^{-8} \mathrm{~mol} \mathrm{~L}^{-1}$ EIMTC in the classical electrochemical cell did not bring expected results. No EIMTC signals were observed. This signal attenuation was related to the serum sample matrix. Therefore, flow-injection analysis in a commercially available wall-jet flow-cell was proposed to resolve this problem. It is well known that the electrochemical detection under hydrodynamically controlled conditions reveals some benefits. Among others, the shear forces of the flowing liquid continuously regenerate the working electrode surface and remove reaction products [20]. Consequently, the selectivity under flow analytical conditions can be improved, which was confirmed by our research (see Section 3.6). 


\subsection{Calibration Curve in Flow System, Precision and Reproducibility}

The SPCE/CNFs sensor coupled with flow system was used for the quantitative determination of a novel promising anticancer agent candidate EIMTC. The flow conditions and SWV parameters are described in Section 2.4. The responses were linear with EIMTC concentrations ranging from $2.0 \times 10^{-9}$ to $2.0 \times 10^{-8} \mathrm{~mol} \mathrm{~L}^{-1}$ and $2.0 \times 10^{-8}$ to $2.0 \times 10^{-7} \mathrm{~mol} \mathrm{~L}^{-1}$ (Figure $7 \mathrm{~A}, \mathrm{~B}$ ). The limits of detection (LOD) and quantification (LOQ) were determined $5.0 \times 10^{-10}$ and $1.7 \times 10^{-9} \mathrm{~mol} \mathrm{~L}^{-1}$, respectively, according to the definitions of $\mathrm{LOD}=3 \mathrm{SD}_{\mathrm{a}} / \mathrm{b}$ and $\mathrm{LOQ}=10 \mathrm{SD}_{\mathrm{a}} / \mathrm{b}\left(\mathrm{SD}_{\mathrm{a}}\right.$-standard deviation of intercept $(\mathrm{n}=3)$; $\mathrm{b}-$ slope of calibration curve) [21].
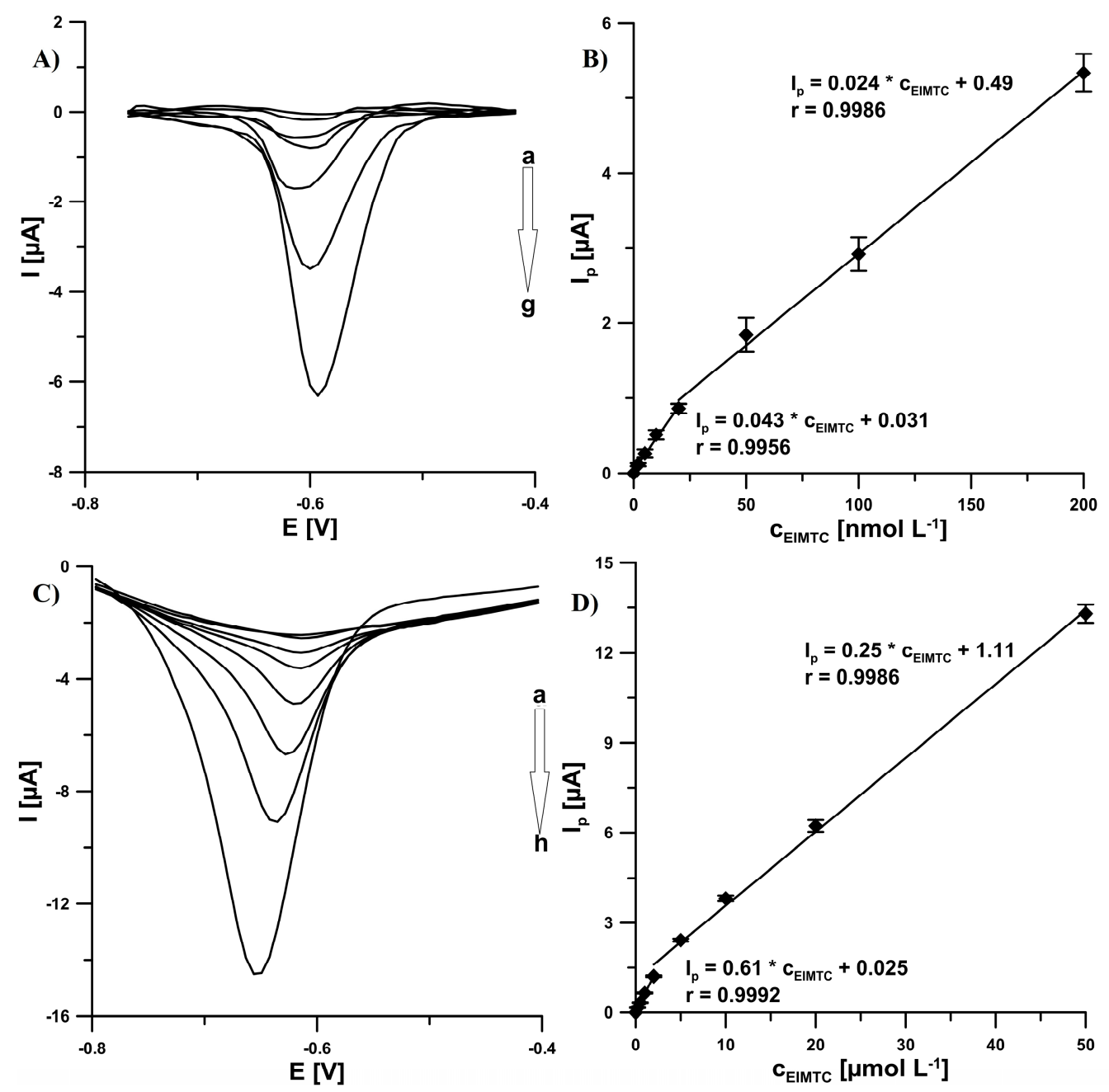

Figure 7. (A) SWV curves registered in flow system at the SPCE/CNFs in $0.075 \mathrm{~mol} \mathrm{~L}^{-1} \mathrm{H}_{2} \mathrm{SO}_{4}$ solution containing increasing concentrations of EIMTC: $2.0 \times 10^{-9}$ (a), $5.0 \times 10^{-9}$ (b), $1.0 \times 10^{-8}$ (c), $2.0 \times 10^{-8}$ (d), $5.0 \times 10^{-8}(\mathrm{e}), 1.0 \times 10^{-7}(\mathrm{f}), 2.0 \times 10^{-7}(\mathrm{~g}) \mathrm{mol} \mathrm{L}^{-1}$. (B) Linear ranges of the calibration graph of EIMTC in flow system at the SPCE/CNFs. (C) SWV curves registered in flow system at the SPCE in $0.075 \mathrm{~mol} \mathrm{~L}^{-1} \mathrm{H}_{2} \mathrm{SO}_{4}$ solution containing increasing concentrations of EIMTC: $2.0 \times 10^{-7}$ (a), $5.0 \times 10^{-7}$ (b), $1.0 \times 10^{-6}$ (c), $2.0 \times 10^{-6}$ (d), $5.0 \times 10^{-6}(\mathrm{e}), 1.0 \times 10^{-5}$ (f), $2.0 \times 10^{-5}$ (g), $5.0 \times 10^{-5}$ (h) $\mathrm{mol} \mathrm{L}^{-1}$. (D) Linear ranges of the calibration graph of EIMTC in flow system at the SPCE. The average values of $I_{p}$ are shown with the standard deviation of $n=9$. After $55 \mathrm{~s}$ (open circuit potential) from the moment of sample injection (500 $\mu \mathrm{L}$ sample loop), SWV measurements were carried out. The SWV parameters: initial $E$ of $-0.2 \mathrm{~V}$, final $E$ of $-0.9 \mathrm{~V}, f$ of $50 \mathrm{~Hz}, \Delta E_{A}$ of $50 \mathrm{mV}$, and $\Delta E_{\text {step }}$ of $7 \mathrm{mV}$.

The relative standard deviation (RSD) values of $2.9 \%$ and $5.2 \%$ calculated for ten repeated measurements of $2.0 \times 10^{-8}$ and $2.0 \times 10^{-7} \mathrm{~mol} \mathrm{~L}^{-1}$ EIMTC at the SPCE/CNFs, respectively, confirmed 
the satisfactory precision of the signals at the SPCE/CNFs. In turn, the RSD values of $3.4 \%$ and $4.7 \%(\mathrm{n}=9)$ calculated for the same EIMTC concentrations but using three electrodes, indicated the acceptable reproducibility of the sensor.

Moreover, in order to confirm the advantage of using the SPCE/CNFs instead of the unmodified SPCE in the EIMTC determinations, the voltammetric measurements to the calibration curve were also made at the SPCE (Figs. 7C and 7D). The calibration curve was linear in two ranges from $2.0 \times 10^{-7}$ to $2.0 \times 10^{-6} \mathrm{~mol} \mathrm{~L}^{-1}$ and from $2.0 \times 10^{-6}$ to $5.0 \times 10^{-5} \mathrm{~mol} \mathrm{~L}^{-1}$, with detection and quantification limits of $3.4 \times 10^{-8}$ and $1.1 \times 10^{-7} \mathrm{~mol} \mathrm{~L}^{-1}$, respectively. The comparison demonstrates that the SPCE/CNFs provides two orders of magnitude lower detection and quantifications limits.

\subsection{Serum Samples Assay in Flow System}

To establish the utility of the developed flow voltammetric procedure in biological samples, EIMTC was determined in the spiked human serum samples. The calibration graph was used for the determination of spiked serum samples. The results obtained for the SWV and UHPLC-ESI-MS/MS analysis are listed in Table 2 . The recovery obtained was $97.2 \%$ and $99.0 \%$. The relative error values of $3.0 \%$ and $7.2 \%$ show satisfactory agreement with the cooperative UHPLC-ESI-MS/MS method. It was also confirmed by the $t-S t u d e n t$ test. The calculated $t$ values $\left(t_{\text {exp. }}\right)$ are 1.98 and 0.71 , which is below the critical value equal to 2.78 (level of significance of 0.05 , number of degrees of freedom $(f)$ of $4, f=n_{1}+$ $n_{2}-2$ ) [22]. Moreover, the results indicate that there is no significant effect of the sample serum matrix on the voltammetric EIMTC signal, and the developed SWV procedure in a flow system is feasible for EIMTC analysis in real biological samples.

Table 2. Results obtained for EIMTC in human serum samples using SWV at the SPCE/CNFs and UHPLC-ESI-MS/MS.

\begin{tabular}{|c|c|c|c|c|c|c|}
\hline & \multicolumn{3}{|c|}{ EIMTC Concentration $\left[\mathrm{mol} \mathrm{L}^{-1}\right] \pm \mathrm{SD}(\mathrm{n}=3)$} & \multirow{2}{*}{$\begin{array}{c}\text { Recovery } \\
{[\%]}\end{array}$} & \multirow{2}{*}{$\begin{array}{l}\text { Relative } \\
\text { Error [\%] }\end{array}$} & \multirow[b]{2}{*}{$t_{\text {exp. }}$} \\
\hline & Added & Found SWV & $\begin{array}{c}\text { Found } \\
\text { UHPLC-ESI-MS/MS }\end{array}$ & & & \\
\hline $\begin{array}{l}\text { Human } \\
\text { serum }\end{array}$ & $\begin{array}{l}5.0 \times 10^{-8} \\
1.0 \times 10^{-7}\end{array}$ & $\begin{array}{l}4.86 \times 10^{-8} \pm 0.17 \times 10^{-8} \\
0.99 \times 10^{-7} \pm 0.03 \times 10^{-7}\end{array}$ & $\begin{array}{l}5.21 \times 10^{-8} \pm 0.05 \times 10^{-8} \\
0.96 \times 10^{-7} \pm 0.03 \times 10^{-7}\end{array}$ & $\begin{array}{l}97.2 \\
99.0\end{array}$ & $\begin{array}{l}7.2 \\
3.0\end{array}$ & $\begin{array}{l}1.98 \\
0.71\end{array}$ \\
\hline
\end{tabular}

\section{Conclusions}

In the present studies, the first analytical method was proposed for sensitive and selective determination of a novel promising anticancer agent candidate (EIMTC) using the carbon nanofibers modified screen-printed carbon sensor. The modified sensor showed great improvement to the EIMTC reduction electrode process compared to the unmodified sensor (LOD: $5.0 \times 10^{-10} \mathrm{~mol} \mathrm{~L}^{-1}$ vs. $3.4 \times$ $10^{-8} \mathrm{~mol} \mathrm{~L}^{-1}$ and $1.7 \times 10^{-9} \mathrm{~mol} \mathrm{~L}^{-1}$ vs. $1.1 \times 10^{-7} \mathrm{~mol} \mathrm{~L}^{-1}$, respectively). The reason for enhanced detection performance at the SPCE/CNFs is related to an increase in the number of active sites, as we showed earlier [14,15]. Furthermore, the electrochemical responses of EIMTC at the SPCE/CNFs were characterized by the $\mathrm{CV}$ technique and the results indicated that the reduction process of EIMTC is diffusion-controlled. The diffusion of EIMTC molecules to the electrode surface was facilitated during solution mixing before the SWV curve registration. Moreover, the flow system successfully resolved the problem with the influence of the human serum matrix on the EIMTC signal. The application of the developed voltammetric procedure for analysis of human serum samples was successfully demonstrated. The results show satisfactory agreement with the cooperative UHPLC-ESI-MS/MS method. The proposed method is characterized by a wide linear range, low detection and quantification limits, as well as satisfactory precision and reproducibility.

Author Contributions: Conceptualization, K.T.-R. and J.K.; methodology, K.T.-R. and J.K.; investigation, K.T.-R., J.K., M.S., K.S. and I.S.; writing-original draft preparation, K.T.-R. and J.K.; writing-review and editing, K.T.-R., J.K., M.S., K.S. and I.S.; supervision, K.T.-R. All authors have read and agreed to the published version of the manuscript. 
Funding: This research received no external funding.

Acknowledgments: The authors gratefully acknowledge the use of the services and facilities of the Center for Interdisciplinary Research of The John Paul II Catholic University of Lublin, Lublin, Poland, supported by the European Union from European Regional Development Fund under the Operational Programme Development of Eastern Poland 2007-2013 (agreement POPW.01.03.00-06-003/09-00).

Conflicts of Interest: The authors declare no conflict of interest.

\section{References}

1. Sztanke, K.; Rzymowska, J.; Niemczyk, M.; Dybała, I.; Kozioł, A.E. Synthesis, Crystal structure and anticancer activity of novel derivatives of ethyl 1-(4-oxo-8-aryl-4,6,7,8tetrahydroimidazo[2,1-c][1,2,4]triazin-3-yl)formate. Eur. J. Med. Chem. 2006, 41, 539-547. [CrossRef] [PubMed]

2. Sztanke, K. New Ethyl 7,8-Dihydro-6H-Imidazo[2,1-c][1,2,4]Triazine-4-oxo-3-Carboxylates and Method for Obtaining Them. Polish Patent 196751, 31 January 2008.

3. Sztanke, M.; Rzymowska, J.; Sztanke, K. In vitro effects of a new fused azaisocytosine-like congener on relative cell proliferation, necrosis and cell cycle in cancer and normal cell cultures. Mol. Cell. Biochem. 2016, 418, 179-188. [CrossRef] [PubMed]

4. Rosolina, S.M.; Chambers, J.Q.; Xue, Z.-L. Direct analysis of palladium in active pharmaceutical ingredients by anodic stripping voltammetry. Anal. Chim. Acta 2016, 914, 47-52. [CrossRef] [PubMed]

5. Li, M.; Li, Y.-T.; Li, D.-W.; Long, Y.-T. Recent developments and applications of screen-printed electrodes in environmental assays-A review. Anal. Chim. Acta 2012, 734, 31-44. [CrossRef] [PubMed]

6. Blasco, C.A.; Plana, N.S.; Cruz, J.M.; Cortada, M.E. Voltammetric determination of metal ions beyond mercury electrodes. A review. Anal. Chim. Acta 2017, 990, 11-53.

7. Raymundo-Pereira, P.A.; Gomes, N.O.; Carvalho, J.H.S.; Machado, S.A.S.; Oliveira, O.N., Jr.; Janegitz, B.C. Simultaneous detection of quercetin and carbendazim in wine samples using disposable electrochemical sensors. ChemElectroChem 2020, 7, 3074-3081. [CrossRef]

8. Silva, R.R.; Raymundo-Pereira, P.A.; Campos, A.M.; Wilson, D.; Otoni, C.G.; Barud, H.S.; Costa, C.A.R.; Domeneguetti, R.R.; Balogh, D.T.; Ribeiro, S.J.L.; et al. Microbial nanocellulose adherent to human skin used in electrochemical sensors to detect metal ions and biomarkers in sweat. Talanta 2020, 218, 121153. [CrossRef] [PubMed]

9. Raymundo-Pereira, P.A.; Gomes, N.O.; Machado, S.A.S.; Oliveira, O.N., Jr. Simultaneous, ultrasensitive detection of hydroquinone, paracetamol and estradiol for quality control of tap water with a simple electrochemical method. J. Electroanal. Chem. 2019, 848, 113319. [CrossRef]

10. Trojanowicz, M. Impact of nanotechnology on design of advanced screen-printed electrodes for different analytical applications. TrAC-Trends Anal. Chem. 2016, 84, 22-47. [CrossRef]

11. Marken, F.; Gerrard, M.L.; Mellor, I.M.; Mortimer, R.J.; Madden, C.E.; Fletcher, S.; Holt, K.; Foord, J.S.; Dahm, R.H.; Page, F. Voltammetry at carbon nanofiber electrodes. Electrochem. Commun. 2001, 3, 177-180. [CrossRef]

12. Huang, J.; Liu, Y.; You, T. Carbon nanofiber based electrochemical biosensors: A review. Anal. Methods 2010, 2, 202-211. [CrossRef]

13. Kour, R.; Arya, S.; Young, S.-J.; Gupta, V.; Bandhoria, P.; Khosla, A. Review-Recent advances in carbon nanomaterials as electrochemical biosensors. J. Electrochem. Soc. 2020, 167, 037555. [CrossRef]

14. Sasal, A.; Tyszczuk-Rotko, K.; Wójciak, M.; Sowa, I. First electrochemical sensor (screen-printed carbon electrode modified with carboxyl functionalized multiwalled carbon nanotubes) for ultratrace determination of diclofenac. Materials 2020, 13, 781. [CrossRef] [PubMed]

15. Sasal, A.; Tyszczuk-Rotko, K.; Wójciak, M.; Sowa, I.; Kuryło, M. Simultaneous analysis of paracetamol and diclofenac using MWCNTs-COOH modified screen-printed carbon electrode and pulsed potential accumulation. Materials 2020, 13, 3091. [CrossRef] [PubMed]

16. Gosser, D.K. Cyclic Voltammetry: Simulation and Analysis of Reaction Mechanism; VCH: New York, NY, USA, 1993. 
17. Sasal, A.; Tyszczuk-Rotko, K.; Chojecki, M.; Korona, T.; Rotko, M. Direct determination of paracetamol in environmental samples using screen-printed carbon/carbon nanofibers sensor-Experimental and theoretical studies. Electroanalysis 2020, 32, 1618-1628. [CrossRef]

18. Ludvik, J.; Zuman, P. Electrochemical proof of the single bond character of the $\mathrm{N}-\mathrm{N}$ bonds in some 1,2,4-triazines. Indian J. Chem. 2003, 42A, 847-848.

19. Stępniowska, A.; Sztanke, M.; Tuzimski, T.; Korolczuk, M.; Sztanke, K. A simple stripping voltammetric method for the determination of a new anticancer prodrug in serum. Biosens. Bioelectron. 2017, 94, 584-588. [CrossRef] [PubMed]

20. Tóth, K.; Štulic, K.; Kutner, W.; Fehér, Z.; Lindner, E. Electrchemical detction in liquid flow analitical techniques: Characterization and classification (IUPAC Technical Report). Pure Appl. Chem. 2004, 76, 1119-1138.

21. Mocak, J.; Bond, A.M.; Mitchell, S.; Scollary, G. A statistical overview of standard (IUPAC and ACS) and new procedures for determining the limits of detection and quantification: Application to voltammetric and stripping techniques. Pure Appl. Chem. 1997, 69, 297-328. [CrossRef]

22. Konieczki, P.; Namiesnik, J. Quality Assurance and Quality Control in the Analytical Chemical Laboratory: A Practical Approach; CRC Press: Boca Raton, FL, USA, 2009.

(C) 2020 by the authors. Licensee MDPI, Basel, Switzerland. This article is an open access article distributed under the terms and conditions of the Creative Commons Attribution (CC BY) license (http://creativecommons.org/licenses/by/4.0/). 